\title{
Hubungan Peningkatan Kadar Progesteron pada saat Pengambilan Oosit terhadap Keberhasilan Fertilisasi In Vitro
}

\author{
Martha Chaterince Silitonga ${ }^{1}$, Shofwal Widad ${ }^{2}$, Ova Emilia ${ }^{3}$ \\ 1,2,3 Departemen Obstetri dan Ginekologi, Fakultas Kedokteran, Kesehatan Masyarakat dan Keperawatan, \\ Universitas Gadjah Mada, Yogyakarta, Indonesia \\ Korespondensi: marthasilitongamd@gmail.com
}

Submisi: 26 Februari 2021; Revisi:25 Maret 2021; Penerimaan: 1 April 2021

\begin{abstract}
Background: In Vitro Fertilization (FIV) is increasingly being used in the treatment of infertility in Indonesia. Many studies have studied the effect of increasing progesterone levels during oocyte uptake on the success of FIV, but the results are controversial.

Objective: To determine the relationship between increased levels of the hormone progesterone when taking oocytes with the success of FIV.

Method: This study used a retrospective cohort method involving 210 FIV cycles from January 2014 to December 2016. Subjects were divided into two groups based on their progesterone levels when taking oocytes. The first group with progesterone levels $<12 \mathrm{ng} / \mathrm{ml}$ were 151 subjects, while 59 others were included in the group with progesterone levels $\geq 12 \mathrm{ng} / \mathrm{ml}$. The pregnancy outcome was assessed by measuring the level of the hormone $\beta$-hCG. Results adn Discussion: There was no significant difference in pregnancy outcome between groups with low progesterone levels and high progesterone levels ( $25.8 \%$ VS $23.7 \%$; RR 0.67 IK $0.29-1.56, p>0,05)$. In the bivariate analysis, there was a significant increase in post-stimulation estradiol levels and the number of follicles (RR 2.00 IK 1.57-2.55, $p<0.0001$ and RR 1.86, Cl 1.47-2.36, $p<0.0001$ ); the number of oocytes (RR 1.99, Cl 1.61-2.48, p<0.0001), and the number of embryos (RR 1.99 IK 1.62-2.43; $p<0.0001$ ) in the group with high progesterone levels. From the multivariate analysis, the increase in oocyte count was the only factor that significantly increased the pregnancy ratio in FIV (RR 3.36 IK 1.04-10.87; p <0.05).

Conclusion: In this study, there was no significant difference between the pregnancy ratio in FIV and the increased levels of the hormone progesterone in oocyte uptake. The number of oocytes harvested significantly increased pregnancy success in FIV, and the number of oocytes was also significantly increased in the group with high progesterone levels.
\end{abstract}

Keywords: IVF; Oocyte; progesterone

\begin{abstract}
ABSTRAK
Latar Belakang: Fertilisasi In Vitro (FIV) semakin banyak digunakan dalam penanganan infertilitas di Indonesia. Banyak penelitian yang mempelajari pengaruh peningkatan kadar progesteron saat pengambilan oosit dalam keberhasilan FIV, namun hasil yang diperoleh masih bersifat kontroversi.

Tujuan: Mengetahui hubungan peningkatan kadar hormon progesteron saat pengambilan oosit dengan keberhasilan FIV.

Metode: Penelitian ini menggunakan metode kohort retrospektif melibatkan 210 siklus FIV dari Januari 2014 sampai Desember 2016. Subyek penelitian dibagi menjadi dua kelompok berdasarkan kadar progesteron saat pengambilan oosit. Kelompok pertama dengan kadar progesteron $<12$ $\mathrm{ng} / \mathrm{ml}$ sebanyak 151 subyek, sedangkan 59 lainnya masuk dalam kelompok dengan kadar progesteron $\geq 12 \mathrm{ng} / \mathrm{ml}$. Luaran kehamilan dinilai dengan mengukur kadar hormon $\beta$-hCG.

Hasil dan Pembahasan: Didapatkan hasil bahwa tidak ada perbedaan bermakna untuk luaran kehamlan antara kelompok dengan kadar progesteron rendah dan kadar progesteron tinggi ( $25,8 \%$ VS $23,7 \%$; RR 0,67 IK 0,29-1,56, p>0,05). Pada analisis bivariat, terdapat peningkatan signifikan dari kadar estradiol pasca stimulasi dan jumlah folikel (RR 2,00 IK 1,57-2,55, p<0,0001 dan RR 1,86, IK 1,47-2,36, p<0,0001); jumlah oosit (RR 1,99, IK 1,61-2,48, $\mathrm{p}<0,0001$ ), dan jumlah embrio (RR 1,99 IK 1,62-2,43; $\mathrm{p}<0,0001$ ) pada kelompok dengan kadar progesteron tinggi. Dari analisis multivariat, peningkatan jumlah oosit merupakan satu - satunya faktor yang secara signifikan meningkatkan rasio kehamilan pada FIV (RR 3,36 IK 1,04-10,87; $p<0,05$ ).

Kesimpulan: Pada penelitian ini tidak terdapat perbedaan signifikan rasio kehamilan pada FIV dengan peningkatan kadar hormon progesteron pada pengambilan oosit. Jumlah oosit yang dipanen secara signifikan meningkatkan keberhasilan kehamilan pada FIV, dan jumlah oosit juga signifikan meningkat pada kelompok dengan kadar progesteron tinggi.
\end{abstract}

Kata Kunci: IVF; Oosit; progesteron 


\section{PENDAHULUAN}

Infertilitas secara umum didefinisikan sebagai hubungan seksual tanpa proteksi selama 1 tahun yang tidak menghasilkan konsepsi. Dalam satu tahun, konsepsi terjadi pada sekitar $85-90 \%$ pasangan muda sehat. Oleh karena itu, kejadian infertilitas sebesar $10-15 \%$ pasangan. ${ }^{1}$

Di Indonesia, angka kejadian infertilitas belum dapat diperkirakan dengan tepat karena pencatatan perkawinan dan kelahiran belum dilaksanakan dengan sempurna, namun diperkirakan tidak berbeda jauh dari angka kejadian secara umum, yaitu sekitar $10-20 \%{ }^{2}$

Pertumbuhan jumlah kasus Fertilisasi In Vitro (FIV)yang ditangani di seluruh klinik infertilitas di Indonesia meningkat sebesar $25 \%$ pada tahun 2015, dimana jumlah kasus mencapai 6008 kasus. ${ }^{3}$ Indikasi terbanyak adalah faktor laki - laki (24,5\%), faktor tuba (12,6\%), disfungsi ovulasi $(5,7 \%)$, endometriosis $(8,1 \%)$, hilangnya cadangan ovarium (6,5\%), dan faktor tak teridentifikasi $(14,9 \%)$ dengan angka keberhasilan total sebesar $30 \% .{ }^{4}$ Hormon progesteron memiliki peranan penting dalam tahapan-tahapan fertilisasi, dimulai dari perkembangan folikel, pematangan oosit, perkembangan embrio, implantasi embrio, reseptivitas endometrium, transformasi sel stroma menjadi sel desidua, bahkan sesudah terjadinya kehamilan. $^{5}$

Efek progesteron dalam kesuksesan FIV telah banyak dipelajari dalam berbagai penelitian dan sampai saat ini masih menjadi perdebatan. ${ }^{6}$ Beberapa penelitian menyimpulkan bahwa peningkatan kadar hormon progesteron pada stimulasi ovarium berhubungan dengan penurunan rasio implantasi dan kehamilan. ${ }^{7-11}$ Namun beberapa penelitian yang lain tidak memperoleh hasil yang mendukung. ${ }^{12-14}$

Faktor - faktor yang mempengaruhi hubungan antara peningkatan kadar hormon progesteron pada akhir fase proliferasi dengan keberhasilan kehamilan sampai saat ini belum diketahui dengan jelas, namun beberapa pendapat ahli mengemukakan kadar progesteron yang tinggi mengakibatkan terjadinya luteinisasi dini. Pendapat yang lain menyebutkan gangguan pengaturan penerimaan embrio pada saat implantasi akibat peningkatan kadar hormon luteinizing (LH), desensitisasi hormon
GnRH (Gonadotropine Releasing Hormone) agonis yang tidak lengkap, peningkatan sensitivitas reseptor hormon LH terhadap sel granulosa yang diakibatkan oleh peningkatan kadar hormon progesterone. . $, 8,11,12,15-17^{-17}$

Pada kebanyakan studi, pengukuran kadar progesteron dalam memprediksi keberhasilan kehamilan dilakukan pada hari pemberian hormon human Chorionic Gonadotropin (hCG). Namun Nayak et al., (2014) melakukan pengukuran kadar progesteronpada saat dilakukan pengambilan oosit, dengan pertimbangan pada hari dilakukan pengambilan oosit, terjadi peningkatan kadar progesteron akibat efek peningkatan $\mathrm{LH}$ endogen disamping terjadinya peningkatan progesteron akibat pemberian hormon hCG. Dari penelitian tersebut disimpulkan peningkatan kadar pogesteron pada saat pengambilan oosit secara signifikan menurunkan rasio implantasi maupun keberhasilan kehamilan pada FIV pada stimulasi ovarium dengan menggunakan protokol pendek GnRH antagonis. ${ }^{11,18}$

\section{METODE}

\section{Desain Penelitian}

Penelitian ini menggunakan desain kohort retrospektif dengan melihat data rekam medis wanita yang mengikuti program Fertilisasi In Vitro sejak Januari 2016 sampai Desember 2017.

\section{Subyek Penelitian}

Subyek penelitian adalah semua wanita yang mengikuti program Fertilisasi In Vitro (FIV) di klinik infertilitas Permata Hati RSUP dr. Sardjito, selama periode Januari 2014 sampai Desember 2016. Kriteria inklusi adalah pasien yang termasuk dalam program FIV dengan fresh cycle dan mengikuti program sampai selesai. Pasien dilakukan pemeriksaan progesteron pada saat pengambilan oosit. Sedangkan kriteria ekslusi adalah wanita dengan poor ovarian response.

\section{Prosedur Penelitian}

Data diambil dari rekam medis wanita yang mengikuti program Fertiilisasi In Vitro di Klinik Permata Hati RSUP dr. Sardjito. Program FIV dimulai dengan 
stimulasi ovarium baik dengan menggunakan protokol panjang dengan agonis $\mathrm{GnrH}$ maupun stimulasi protokol pendek dengan antagonis GnRH. Pada akhir stimulasi, diberikan hormone hCG untuk memicu terjadinya stimulasi. Sekitar 36 jam sesudahnya, dilakukan pengambilan oosit. Pada saat ini juga dilakukan pengukuran kadar progesteron. Sekitar tiga hari (72 jam ) sesudahnya, prosedur dilanjutkan dengan transfer embrio. Empat belas hari sesudah transfer embrio, kadar hormon $\beta$-hCG diukur, dimana dikatakan hamil apabila kadar hormon $\beta$-hCG $>25 \mathrm{mlU} / \mathrm{mL}$.

\section{Analisis Statistika}

Data dianalisis dengan menggunakan analisis univariat untuk menentukan karakteristik subyek penelitian, analisis bivariat untuk membandingkan karakteristik pada kedua grup, dan mengetahui hubungan antara variable luar dan luaran penelitian. Analisis multivariat dengan menggunakan regresi logistik. Data dianalisis dengan menggunakan program perangkat lunak SPSS 23.0.

\section{HASIL DAN PEMBAHASAN}

\section{Karakteristik Sampel Penelitian}

Rata-rata umur wanita yang mengikuti programFIV adalah 34 tahun, dengan indikasi infertillitas terbesar adalah faktor laki-laki sebanyak 74 orang $(35,2 \%)$ diikuti dengan adanya gangguan tuba sebanyak 47 orang $(22,4 \%)$. Lima puluh tiga pasien $(25,2 \%)$ berhasil hamil, dimana 11 diantaranya mengalami keguguran $(5,2 \%)$. Dua puluh delapan wanita $(13,3 \%)$ berhasil mencapai persalinan dengan kelahiran hidup, dan selebihnya masih dalam kondisi hamil. Seratus lima puluh tujuh kasus (74.8\%) tidak berhasil mengalami konsepsi (Tabel 1). Karakteristik masing-masing kelompok ditunjukkan pada Tabel 2.

Tabel 1. Karakteristik Subyek Penelitian

\begin{tabular}{lc}
\multicolumn{1}{c}{ Variabel } & Median (min-maks) \\
\hline Usia (tahun) & $34(19-45)$ \\
Nullipara (\%) & $90,5(190)$ \\
IMT $\left(\mathrm{kg} / \mathrm{m}^{2}\right)$ & $23(16-33)$ \\
Tipe Infertilitas & \\
Primer & $71,9(151)$ \\
Sekunder & $28,1(59)$
\end{tabular}

\begin{tabular}{lc}
\multicolumn{1}{c}{ Variabel } & Median (min-maks) \\
Lama Infertilitas (tahun) & $6(1-17)$ \\
Jumlah Folikel Antral & $9(2-30)$ \\
Kadar AMH (ng/ml) & $2,57(0,18-30,1)$ \\
Jenis Stimulasi Ovarium & $81(170)$ \\
$\quad$ Protokol antagonis & $19(40)$ \\
$\quad$ Protokol panjang & $2025(750-3750)$ \\
Total dosis gonadotropin & \\
(IU/L) & $1700(177-10810)$ \\
Kadar Estradiol pasca & \\
stimulasi (pg/ml) & $15(3-51)$ \\
Total folikel pasca stimulasi & $8(1-26)$ \\
Jumlah oosit & $4(1-16)$ \\
Jumlah embrio & $2(1-3)$ \\
Jumlah embrio transfer & $25,2(53)$ \\
Rasio kehamilan (\%) & $5,2(11)$ \\
Rasio abortus (\%) & $13,3(28)$ \\
Rasio kelahiran hidup (\%) &
\end{tabular}

${ }^{*}$ Data ditampilkan dalam bentuk jumlah, persentase, median dan rentang. IMT: Indeks Massa Tubuh; AMH: Anti Mullerian Hormone.

Tidak terdapat perbedaan yang signifikan antara kedua kelompok dalam jenis infertilitas, protokol stimulasi ovarium, lama infertilitas dan total gonadotropin. Data ini menunjukkan bahwa penyebaran karakteristik pada variabel - variabel tersebut homogen pada kedua kelompok.

Pada beberapa variabel terdapat perbedaan yang signifikan yang menunjukkan penyebaran karakteristik yang tidak homogen pada kedua kelompok. Variabel - variabel tersebut antara lain; usia, IMT, kadar AMH,jumlah folikel antral, kadar estradiol akhir stimulasi, jumlah total folikel akhir stimulasi, jumlah oosit dan jumlah embrio yang lebih tinggi $(p<0,05)$ (Tabel.2).

\section{Analisis Bivariat Variabel Bebas, Variabel Luar dengan Luaran Kehamilan}

Analisis bivariat dilakukan untuk menilai hubungan antara masing-masing variabel terhadap keberhasilan kehamilan. Faktor yang secara signifikan mempengaruhi kehamilan adalah jumlah oosit ( RR 1,78 IK 1,07-2,97, p 0,02) (Tabel 3).

Demikian juga halnya dengan kadar progesteron, tidak terdapat perbedaan yang signifikan pada 
kelompok studi dengan kadar progesteron rendah dengan kelompok studi dengan kadar progesteron tinggi. Dengan hasil yang tidaksignifikan, kami mencoba untuk menilai ambang batas kadar progesteron yang dapat menjadi titik potong (cut off point) peningkatan kadar progesteron. Gambar 1 menunjukkan kurva ROC (Receiving-operating Characteristic) dengan menggunakan kadar hormone progesteron pada saat pengambilan oosit untuk menentukan cut off point kadar progesteron yang dapat memprediksi keberhasilan FIV. Namun dengan diperolehnya kadar Area Under Curve (AUC) 0,42 dengan interval kepercayaan 0,33-0,51, kurva ini memiliki nilai prediksi yang tidak baik sehingga tidak dapat digunakan.

Analisis bivariat dilakukan untuk melihat hubungan antara variabel-variabel luar dengan tingginya kadar progesetron (Tabel 5).

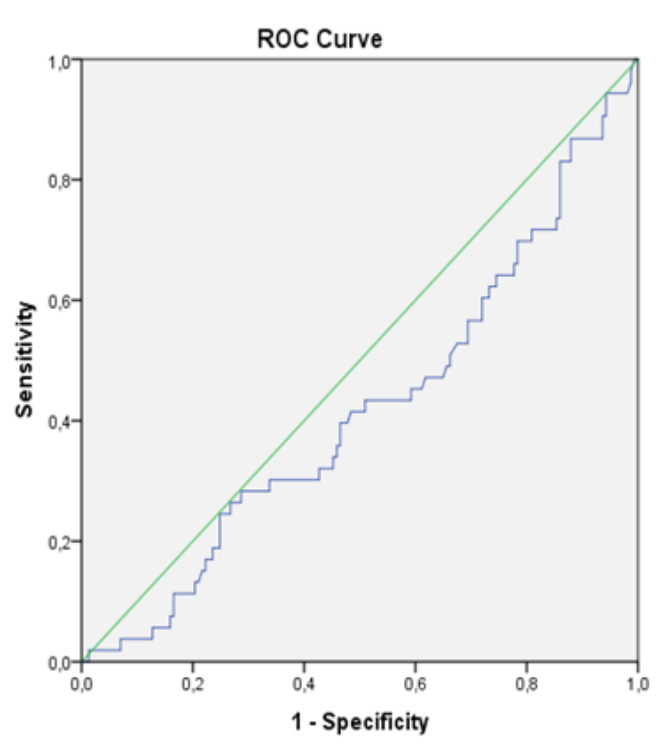

Diagonal segments are produced by ties.

Gambar 1. Kurva ROC Kadar Progesteron dengan Kehamilan

Tabel 2. Karakteristik Klinis Pasien pada Kelompok Penelitian Kadar Progesteron Rendah dan Kadar Progesteron Tinggi

\begin{tabular}{|c|c|c|c|}
\hline Variabel & $\begin{array}{c}\text { Kadar progesteron }<12 \\
\mathrm{ng} / \mathrm{ml} \text { (rendah) } \\
(\mathrm{n}=151)\end{array}$ & $\begin{array}{c}\text { Kadar progesteron } \geq 12 \\
\mathrm{ng} / \mathrm{ml} \text { (tinggi) } \\
(\mathrm{n}=59)\end{array}$ & $\mathbf{p}$ \\
\hline Umur (tahun) & $35(19-45)$ & $32(20-39)$ & 0,0001 \\
\hline Nullipara (\%) & 70,5 (133) & $29,5(57)$ & 0,18 \\
\hline $\begin{array}{l}\text { Tipe infertilitas (\%) } \\
\text { primer } \\
\text { sekunder }\end{array}$ & $\begin{array}{c}69,5(105) \\
78(46)\end{array}$ & $\begin{array}{c}30,5(46) \\
22(13)\end{array}$ & 0,19 \\
\hline Lama infertilitas (tahun) & $6(1-17)$ & $5(1-13)$ & 0,48 \\
\hline $\begin{array}{l}\text { Indikasi infertilitas (\%) } \\
\text { tuba } \\
\text { endometriosis } \\
\text { gangguan ovulasi } \\
\text { uterus } \\
\text { faktor laki-laki } \\
\text { tak teridentifikasi }\end{array}$ & $\begin{array}{c}68,1 \%(32) \\
72,7 \%(24) \\
78,9 \%(15) \\
83,3 \%(10) \\
68,9 \%(51) \\
76 \%(19)\end{array}$ & $\begin{array}{c}31,9 \%(15) \\
27,3 \%(9) \\
21,1 \%(4) \\
16,7 \%(2) \\
31,1 \%(23) \\
24 \%(6)\end{array}$ & 0,86 \\
\hline $\mathrm{IMT}\left(\mathrm{kg} / \mathrm{m}^{2}\right)$ & $23,2(16-33)$ & $21,9(16-33)$ & 0,02 \\
\hline Jumlah folikel antral & $7(2-24)$ & $11(2-30)$ & 0,0001 \\
\hline $\begin{array}{l}\text { Jenis protokol (\%) } \\
\text { antagonis } \\
\text { protokol panjang }\end{array}$ & $\begin{array}{c}70,9 \%(117) \\
71,1 \%(27)\end{array}$ & $\begin{array}{l}29,1 \%(48) \\
28,9 \%(11)\end{array}$ & 0,98 \\
\hline AMH (ng/ml) & $2,37(0,18-16,25)$ & $3,9(1,49-30,1)$ & 0,0001 \\
\hline Total gonadotropin (IU/L) & $2025(750-3750)$ & $2025(1200-3525)$ & 0,49 \\
\hline Kadar estradiol (pg/ml) & $1421(177-10580)$ & 2800 (801-10810) & 0,0001 \\
\hline Jumlah folikeltotal & $12(1-33)$ & $20(6-51)$ & 0,0001 \\
\hline Jumlah oosit & $6(1-23)$ & $12(3-26)$ & 0,0001 \\
\hline Jumlah embrio & $3(1-10)$ & $6(2-16)$ & 0,0001 \\
\hline
\end{tabular}

") Data disajikan dalam bentuk jumlah, persentase (\%), median, range. IMT: Indeks Massa Tubuh; AMH: Anti Mullerian Hormon. 
Diperoleh peningkatan yang signifikan dari kadar progeseteron $\geq 12 \mathrm{ng} / \mathrm{ml}$ pada kelompok umur yang $\geq 34$ tahun (RR 2,17 IK 1,39-3,39, p<0,0001), IMT <25 $\mathrm{kg} / \mathrm{m} 2$, (RR 1,92 IK 1,02-3,64, p<0,05) jumlah folikel antral $>5$ (RR 2,81, IK 1,64-4,8, p< 0,0001), kadar $\mathrm{AMH} \geq 2,57 \mathrm{ng} / \mathrm{ml}$ ( RR 1,88 IK 1,12-2,99, $\mathrm{p}<0,006$ ), kadar estradiol pasca stimulasi $\geq 1700 \mathrm{pg} / \mathrm{ml}$ ( RR $3,77$, IK 2,1-6,68, $p<0,0001)$, jumlah folikel $>15$ saat akhir stimulasi ( $R R$ 1,86; IK 1,47-2,36, $p<0,0001$ ), jumlah total oosit yang dipanen $>8$ (RR 4,67; IK2,4$9,0, p<0,0001)$, serta jumlah embrio yang diperoleh $>4$ (RR 5,68; IK 2,7-11,9; $p<0,0001)$.

\section{Analisis Multivariat Variabel Bebas, dan Variabel Luar dengan Luaran Kehamilan}

Variabel-variabel yang signifikan mempengaruhi peningkatan kadar progesteron dan kehamilan pada analisis bivariat, dianalisis kembali dengan menggunalan analisis multivariat regresi logistic (Tabel 7). Hasil yang diperoleh, jumlah oosit secara signifikan mempengaruhi kehamilan (RR 3,36 IK $1,04-10,87$, p 0,04).

Tabel 3. Analisis Bivariat Karakteristik Variabel Luar dengan Kadar Progesteron

\begin{tabular}{|c|c|c|c|c|c|c|c|}
\hline \multirow{2}{*}{ Variabel } & & \multicolumn{2}{|c|}{$\begin{array}{c}\text { Kadar tinggi } \geq 12 \\
\mathrm{ng} / \mathrm{ml}\end{array}$} & \multicolumn{2}{|c|}{$\begin{array}{l}\text { Kadar rendah } \\
<12 \mathrm{ng} / \mathrm{ml}\end{array}$} & \multirow{2}{*}{ RR (IK 95\%) } & \multirow{2}{*}{$p$} \\
\hline & & $\mathrm{n}$ & $\%$ & $\mathrm{~N}$ & $\%$ & & \\
\hline Usia (tahun) & $\begin{array}{l}\leq 35 \\
>35\end{array}$ & $\begin{array}{l}36 \\
23\end{array}$ & $\begin{array}{l}40,9 \\
18,9\end{array}$ & $\begin{array}{l}52 \\
99\end{array}$ & $\begin{array}{l}59,2 \\
81,1\end{array}$ & $2,17(1,39-3,39)$ & $<0,0001$ \\
\hline IMT ( kg/m²) & $\begin{array}{l}<25 \\
\geq 25\end{array}$ & $\begin{array}{c}50 \\
9\end{array}$ & $\begin{array}{l}32,1 \\
16,7\end{array}$ & $\begin{array}{c}106 \\
45\end{array}$ & $\begin{array}{l}67,9 \\
83,3\end{array}$ & $1,92(1,02-3,64)$ & 0,03 \\
\hline Tipe infertilitas & $\begin{array}{l}\text { primer } \\
\text { sekunder }\end{array}$ & $\begin{array}{l}46 \\
13\end{array}$ & $\begin{array}{l}30,5 \\
28,1\end{array}$ & $\begin{array}{c}105 \\
46\end{array}$ & $\begin{array}{l}69,5 \\
71,8\end{array}$ & $1,38(0,75-1,06)$ & 0,22 \\
\hline $\begin{array}{l}\text { Lama infertilitas } \\
\text { (tahun) }\end{array}$ & $\begin{array}{l}<3 \\
\geq 3\end{array}$ & $\begin{array}{l}32 \\
27\end{array}$ & $\begin{array}{l}31,7 \\
24,8\end{array}$ & $\begin{array}{l}69 \\
82\end{array}$ & $\begin{array}{l}68,3 \\
75,2\end{array}$ & $1,28(0,83-1,97)$ & 0,26 \\
\hline Jumlah folikel antral & $\begin{array}{l}\geq 8 \\
<8\end{array}$ & $\begin{array}{l}41 \\
14\end{array}$ & $\begin{array}{l}39,8 \\
14,1\end{array}$ & $\begin{array}{l}62 \\
85\end{array}$ & $\begin{array}{l}60,2 \\
85,9\end{array}$ & $2,81(1,64-4,8)$ & $<0,0001$ \\
\hline $\mathrm{AMH}(\mathrm{ng} / \mathrm{ml})$ & $\begin{array}{l}\geq 1,4 \\
<1,4\end{array}$ & $\begin{array}{l}39 \\
20\end{array}$ & $\begin{array}{l}36,4 \\
19,4\end{array}$ & $\begin{array}{l}68 \\
83\end{array}$ & $\begin{array}{l}63,6 \\
80,6\end{array}$ & $1,88(1,18-2,99)$ & 0,006 \\
\hline Protokol stimulasi & $\begin{array}{l}\text { Antagonis } \\
\text { Protokol panjang }\end{array}$ & $\begin{array}{l}48 \\
11\end{array}$ & $\begin{array}{l}28,2 \\
27,5\end{array}$ & $\begin{array}{c}122 \\
29\end{array}$ & $\begin{array}{l}71,8 \\
72,5\end{array}$ & $1,03(0,59-1,79)$ & 0,93 \\
\hline $\begin{array}{l}\text { Dosis gonadotropin } \\
\text { (IU/L) }\end{array}$ & $\begin{array}{l}<2025 \\
\geq 2025\end{array}$ & $\begin{array}{l}25 \\
34\end{array}$ & $\begin{array}{l}29,4 \\
27,2\end{array}$ & $\begin{array}{l}60 \\
91\end{array}$ & $\begin{array}{l}70,6 \\
72,8\end{array}$ & $1,08(0,69-1,67)$ & 0,73 \\
\hline $\begin{array}{l}\text { Kadar E2 akhir } \\
\text { stimulasi (pg/ml) }\end{array}$ & $\begin{array}{l}\geq 1100 \\
<1100\end{array}$ & $\begin{array}{l}47 \\
12\end{array}$ & $\begin{array}{l}44,3 \\
11,8\end{array}$ & $\begin{array}{l}59 \\
90\end{array}$ & $\begin{array}{l}55,7 \\
88,9\end{array}$ & $3,77(2,1-6,68)$ & $<0,0001$ \\
\hline Jumlah folikel total & $\begin{array}{l}\geq 15 \\
<15\end{array}$ & $\begin{array}{l}44 \\
13\end{array}$ & $\begin{array}{l}41,9 \\
13,1\end{array}$ & $\begin{array}{l}61 \\
86\end{array}$ & $\begin{array}{l}58,1 \\
86,9\end{array}$ & $3,19(1,8-5,5)$ & $<0,0001$ \\
\hline Jumlah oosit & $\begin{array}{l}\geq 8 \\
<8\end{array}$ & $\begin{array}{c}50 \\
9\end{array}$ & $\begin{array}{c}43,9 \\
9,4\end{array}$ & $\begin{array}{l}64 \\
87\end{array}$ & $\begin{array}{l}56,1 \\
90,6\end{array}$ & $4,67(2,4-9,0)$ & $<0,0001$ \\
\hline Jumah embrio & $\begin{array}{l}\geq 4 \\
<4\end{array}$ & $\begin{array}{c}52 \\
7\end{array}$ & $\begin{array}{c}43,7 \\
7,7\end{array}$ & $\begin{array}{l}67 \\
84\end{array}$ & $\begin{array}{l}56,3 \\
92,3\end{array}$ & $5,68(2,7-11,9)$ & $<0,0001$ \\
\hline
\end{tabular}

Ket; E2: estradiol, IMT: Indeks Massa Tubuh, AMH: Anti Mullerian Hormon 
Tabel 4. Hubungan Variabel Luar dengan Kehamilan

\begin{tabular}{|c|c|c|c|c|c|c|c|}
\hline \multirow{2}{*}{ Variabel } & & \multicolumn{2}{|c|}{ Hamil } & \multicolumn{2}{|c|}{ Tidak hamil } & \multirow{2}{*}{$\begin{array}{c}\text { RR } \\
\text { (IK 95\%) }\end{array}$} & \multirow{2}{*}{$\mathbf{p}$} \\
\hline & & n & $\%$ & $\mathbf{n}$ & $\%$ & & \\
\hline $\begin{array}{l}\text { Kadar progesteron } \\
\text { saat pengambilan } \\
\text { oosit (ng/ml) }\end{array}$ & $\begin{array}{l}<12 \\
\geq 12\end{array}$ & $\begin{array}{l}39 \\
14\end{array}$ & $\begin{array}{l}25,8 \\
23,7\end{array}$ & $\begin{array}{l}112 \\
45\end{array}$ & $\begin{array}{l}74,2 \\
76,3\end{array}$ & $1,09(0,64-1,85)$ & 0,75 \\
\hline Usia (tahun) & $\begin{array}{l}\leq 35 \\
>35\end{array}$ & $\begin{array}{l}20 \\
33\end{array}$ & $\begin{array}{l}22,7 \\
27\end{array}$ & $\begin{array}{l}68 \\
89\end{array}$ & $\begin{array}{l}77,3 \\
73\end{array}$ & $0,84(0,5-1,4)$ & 0,47 \\
\hline Paritas & $\begin{array}{l}\text { Nullipara } \\
\text { Primi/multipara }\end{array}$ & $\begin{array}{l}47 \\
6\end{array}$ & $\begin{array}{l}24,7 \\
30\end{array}$ & $\begin{array}{l}143 \\
14\end{array}$ & $\begin{array}{l}75,3 \\
70,0\end{array}$ & $0,83(0,4-0,68)$ & 0,61 \\
\hline IMT ( kg/m2) & $\begin{array}{l}<25 \\
\geq 25\end{array}$ & $\begin{array}{l}37 \\
16\end{array}$ & $\begin{array}{l}23,7 \\
29,6\end{array}$ & $\begin{array}{l}119 \\
38\end{array}$ & $\begin{array}{l}76,3 \\
70,4\end{array}$ & $0,8(0,48-1,32)$ & 0,39 \\
\hline $\begin{array}{l}\text { Lama Infertil } \\
\text { (tahun) }\end{array}$ & $\begin{array}{l}<3 \\
\geq 3\end{array}$ & $\begin{array}{l}22 \\
31\end{array}$ & $\begin{array}{l}21,8 \\
28,4\end{array}$ & $\begin{array}{l}79 \\
78\end{array}$ & $\begin{array}{l}78,2 \\
71,6\end{array}$ & $0,7(0,37-1,31)$ & 0,27 \\
\hline Tipe infertilitas & $\begin{array}{l}\text { Primer } \\
\text { Sekunder }\end{array}$ & $\begin{array}{l}33 \\
20\end{array}$ & $\begin{array}{l}21,9 \\
33,9\end{array}$ & $\begin{array}{l}118 \\
39\end{array}$ & $\begin{array}{l}78,1 \\
66,1\end{array}$ & $0,65(0,4-1,03)$ & 0,07 \\
\hline $\begin{array}{l}\text { Jumlah folikel } \\
\text { antral }\end{array}$ & $\begin{array}{l}\geq 8 \\
<8\end{array}$ & $\begin{array}{l}29 \\
21\end{array}$ & $\begin{array}{l}28,2 \\
21,2\end{array}$ & $\begin{array}{l}74 \\
78\end{array}$ & $\begin{array}{l}71,8 \\
78,8\end{array}$ & $1,33(0,81-2,17)$ & 0,25 \\
\hline $\mathrm{AMH}(\mathrm{ng} / \mathrm{ml})$ & $\begin{array}{l}\geq 1.4 \\
<1.4\end{array}$ & $\begin{array}{l}46 \\
7\end{array}$ & $\begin{array}{l}86.8 \\
13.2\end{array}$ & $\begin{array}{l}119 \\
38\end{array}$ & $\begin{array}{l}75.8 \\
24.2\end{array}$ & $0.59(0,81-1,11)$ & 0,06 \\
\hline Stimulasi & $\begin{array}{l}\text { Antagonis } \\
\text { Protokol panjang }\end{array}$ & $\begin{array}{l}39 \\
14\end{array}$ & $\begin{array}{l}23,1 \\
35\end{array}$ & $\begin{array}{l}131 \\
26\end{array}$ & $\begin{array}{l}77,1 \\
65\end{array}$ & $0,65(0,40-1,09)$ & 0,11 \\
\hline $\begin{array}{l}\text { Dosis } \\
\text { gonadotropin } \\
\text { (IU/L) }\end{array}$ & $\begin{array}{l}<2025 \\
\geq 2025\end{array}$ & $\begin{array}{l}25 \\
28\end{array}$ & $\begin{array}{l}29,4 \\
22,4\end{array}$ & $\begin{array}{l}60 \\
97\end{array}$ & $\begin{array}{l}70,6 \\
77,6\end{array}$ & $1,31(0,83-2,09)$ & 0,25 \\
\hline $\begin{array}{l}\text { Kadar estradiol } \\
\text { akhir stimulasi } \\
(\mathrm{pg} / \mathrm{ml})\end{array}$ & $\begin{array}{l}\geq 1100 \\
<1100\end{array}$ & $\begin{array}{l}30 \\
23\end{array}$ & $\begin{array}{l}28,3 \\
23\end{array}$ & $\begin{array}{l}76 \\
79\end{array}$ & $\begin{array}{l}71,7 \\
74,5\end{array}$ & $1,26(0,78-2,0)$ & 0,34 \\
\hline $\begin{array}{l}\text { Jumlah folikel } \\
\text { total }\end{array}$ & $\begin{array}{l}\geq 15 \\
<15\end{array}$ & $\begin{array}{l}30 \\
22\end{array}$ & $\begin{array}{l}28,6 \\
22,2\end{array}$ & $\begin{array}{l}75 \\
77\end{array}$ & $\begin{array}{l}71,4 \\
77,8\end{array}$ & $1,29(0,79-2,07)$ & 0,30 \\
\hline Jumlah oosit & $\begin{array}{l}\geq 8 \\
<8\end{array}$ & $\begin{array}{l}36 \\
17\end{array}$ & $\begin{array}{l}31,6 \\
17,7\end{array}$ & $\begin{array}{l}78 \\
79\end{array}$ & $\begin{array}{l}68,4 \\
82,3\end{array}$ & $1,78(1,07-2,97)$ & 0,021 \\
\hline Jumah embrio & $\begin{array}{l}\geq 4 \\
<4\end{array}$ & $\begin{array}{l}33 \\
20\end{array}$ & $\begin{array}{l}27,7 \\
22,0\end{array}$ & $\begin{array}{l}86 \\
71\end{array}$ & $\begin{array}{l}72,3 \\
78,0\end{array}$ & $1,26(0,78-1,08)$ & 0,34 \\
\hline
\end{tabular}

Pada penelitian kali ini didapatkan tidak ada perbedaan bermakna antara peningkatan kadar progesteron dengan keberhasilan pada fertilisasi invitro. Hasil ini sesuai dengan penelitian yang dilakukan oleh Niu et al., (2008), dimana menyimpulkan bahwa kadar hormonprogesteron saat pengambilan oosit dapat memprediksi kuantitas embrio yang viabel, tetapi tidak dapat memprediksi luaran kehamilan. ${ }^{20}$ Penelitian yang meneliti 289 orang wanita yang menjalani program bayi tabung dengan menggunakan teknik fertilisasi
Intracytoplasmic Sperm Injection (ICSI) ini membagi subyek penelitian menjadi kelompok dengan kadar progesteron saat pengambilan oosit yang rendah dan kelompok kadar progesteron tinggi dengan batas nilai progesteron yang digunakan adalah 11,7 $\mathrm{ng} / \mathrm{ml}$. Dari penelitian tersebut ditemukan bahwa progesteron yang tinggi saat pengambilan oosit berhubungan dengan peningkatan yang signifikan pada jumlah folikel, jumlah oosit dan jumlah embrio, tetapi tidak ada perbedaan yang signifikan pada rasio kehamilan. 
Tabel 5. Analisis Multivariat Regresi Logistik Peningkatan Kadar Progesteron Terhadap Kehamilan

\begin{tabular}{|c|c|c|c|c|c|c|c|c|}
\hline \multirow{2}{*}{ Variabel } & \multirow{2}{*}{ Koefisien } & \multirow{2}{*}{ S.E. } & \multirow{2}{*}{ Wald } & \multirow{2}{*}{ df } & \multirow[t]{2}{*}{ RR } & \multicolumn{2}{|c|}{ IK 95\% } & \multirow{2}{*}{$\mathbf{P}$} \\
\hline & & & & & & Min. & Maks. & \\
\hline $\begin{array}{l}\text { Kadar progesteron } \\
(\mathrm{ng} / \mathrm{ml})\end{array}$ & $-0,40$ & 0,43 & 0,857 & 1 & 0,67 & 0,29 & 1,56 & 0,36 \\
\hline IMT $\left(\mathrm{kg} / \mathrm{m}^{2}\right)$ & 0,02 & 0,55 & 0,001 & 1 & 1,02 & 0,35 & 2,97 & 0,98 \\
\hline Umur (tahun) & 0,57 & 0,38 & 2,268 & 1 & 0,57 & 0,27 & 1,19 & 0,13 \\
\hline $\begin{array}{l}\text { Jumlah folikel } \\
\text { antral }\end{array}$ & 0,38 & 0,40 & 0,881 & 1 & 1,46 & 0,66 & 3,23 & 0,35 \\
\hline AMH (ng/ml) & 0,12 & 0,41 & 0,081 & 1 & 1,12 & 0,51 & 2,49 & 0,78 \\
\hline Estradiol (pg/ml) & $-0,03$ & 0,41 & 0,004 & 1 & 0,98 & 0,44 & 2,17 & 0,95 \\
\hline Total folikel & $-0,22$ & 0,49 & 0,200 & 1 & 0,80 & 0,31 & 2,10 & 0,66 \\
\hline Jumlah oosit & 1,21 & 0,60 & 4,079 & 1 & 3,36 & 1,04 & 10,87 & 0,04 \\
\hline Jumlah embrio & $-0,20$ & 0,49 & 0,162 & 1 & 0,82 & 0,32 & 2,13 & 0,69 \\
\hline Konstanta & 1,22 & 0,50 & 5,951 & 1 & 3,39 & & & 0,02 \\
\hline
\end{tabular}

Dari hasil penelitian yang diperoleh, diperkirakan bahwa progesteron saat pengambilan oosit memiliki peranan dalam perkembangan oosit dan mempengaruhi kualitas embrio, namun tidak berpengaruh pada reseptivitas endometrium pada proses implantasi, sehingga tidak dapat memprediksi kehamilan. ${ }^{20}$ Hasil yang sama juga disampaikan oleh penelitian yang dilakukan oleh Donarini et al., (2010) dimana dari 79 wanita mengikuti program bayi tabung, kadar progesteron pada pengambilan oosit tidak secara signifikan mempengaruhi rasio kehamilan, namun secara signifikan mempengaruhi jumlah folikel berukuran $>15 \mathrm{~mm}$, jumlah oosit dan jumlah embrio. Penelitian ini tidak mencantumkan titik potong kadar progesteron saat pengambilan oosit. ${ }^{19}$

Hasil yang kami diperoleh pada penelitian kali ini berbeda dengan penelitian yang dilakukan oleh Nayak et al., (2014) pada 189 wanita yang mengikuti program FIV dengan stimulasi ovarium mengggunakan protokol $\mathrm{GnRH}$ antagonis. ${ }^{11}$ Subyek penelitian dikelompokkan menjadi dua group dengan batasan kadar progesteron $12 \mathrm{ng} /$ $\mathrm{ml}$, menjadi kelompok dengan kadar hormon progesteron tinggi dan kelompok dengan kadar hormon progesteron rendah. Terdapat penurunan yang signifikan terhadap keberhasilan kehamilan pada kelompok dengan kadar progesteron tinggi. Hal ini diperkirakan karena adanya pengaruh hormonprogesteronpada reseptivitas endometrium terhadap embrio sehingga mempengaruhi kejadian implantasi embrio.

Pada FIV, stimulasi ovarium menyebabkan perkembangan folikuler yang meningkat dan peningkatan kadar estradiol melebihi normal pada fase folikuler dan peningkatan kadar progestron pada fase luteal. Kadar hormon - hormon ini sangat mempengaruhi viabilitas embrio yang didapat dari oosit dengan kualitas baik dan sinkronisasi endometrium yang sangat dibutuhkan untuk mencapai kehamilan. Salah satu fungsi penting sel granulosa adalah sintesis estrogen, sehingga dapat diterima bahwa peningkatan kadar estrogen berhubungan dengan kualitas fungsi oosit. Namun beberapa studi menunjukkan bahwa pada responder tinggi, kadar estradiol yang tinggi tidak selalu berhubungan dengan meningkatnya embrio yang viable. ${ }^{6,21}$

Pada penelitian ini diperoleh hasil bahwa tidak adaperbedaan signifikan antara peningkatan kadar hormonprogesteron saat pengambilan oosit dengan kejadian kehamilan pada FIV. Kemungkinan perbedaan hasil penelitian ini dengan penelitian sebelumnya yang dilakukan oleh Nayak et al., (2014) disebabkan oleh beberapa faktor. ${ }^{11}$ Dari sisi metodologi, pada penelitian ini, jumlah sampel pada kedua kelompok berbeda dengan beberapa karakteristik yang tidak homogen seperti usia, IMT, 
jumlah folikel antral, kadar estradiol pasca stimulasi, jumlah oosit dan jumlah embrio. Seperti yang telah diketahui, faktor-faktor tersebut juga mempengaruhi keberhasilan FIV, sehingga penyebaran subyek penelitian yang tidakhomogen dapat mempengaruhi hasil penelitian.

Keberhasilan FIV dipengaruhi oleh banyak faktor, dimana pada setiap tahapan proses yang dilakukan memiliki faktor - faktor luar yang dapat mempengaruhi keberhasilannya. Hal ini menyebabkan kesulitan dalam upaya mengontrolvariabel perancu, karena tindakan restriksi dan matching pada variabel perancu yang banyak dapat menyebabkan kesulitan untuk memperoleh sampel. Pertimbangan lainnya adalah walaupun banyak faktor yang diperkirakan mempengaruhi keberhasilan FIV, namun hasil hasil penelitian yang telah dilakukan masih bersifat kontroversi, sehingga apabila dilakukan matching terhadap semua faktor yang mempengaruhi maka kemungkinan bisa terjadi overmatching dimana kemungkinan variabel tersebut sebenarnya bukan merupakan perancu pada penelitian ini. ${ }^{16,17,22-24}$

Desain penelitian yang digunakan adalah kohort restrospektif. Hal ini menyebabkan kekurangan dalam mendapatkan data dengan lengkap dan kesulitan dalam mengontrol variabel luar karena sangat tergantung pada kelengkapan data yang sudah ada dan tertulis pada rekam medis subyek penelitian.

Pengukuran peningkatan kadar progesteron sering dilakukan pada hari pemberian hormon hCG maupun hari pengambilan oosit. Beebrapa pertimbangan melakukan pengukuran saat pemberian hCG adalah karena adanya peningkatan sekresi LH pada fase folikuler akhir stimulasi ovarium akan menstimulasi sel granulosa untuk mensekresi progesteron. Dan peningkatan progesteron ini lah yang nanti juga akan berdampak pada terjadinya asinkronisasi antara perubahan endometrium dengan perkembangan embrio. Namun karena hormon hCG memiliki reseptor yang sama dengan LH serta memiliki efek yang jauh lebih besar, sehingga pemberian hCG juga dapat meningkatkan kadar hormon progesteron. Oleh karena itu, adanya peningkatan kadar progesteron pada pemberian hCG dianggap memiliki nilai prediksi yang lebih baik. ${ }^{13,25,26}$
Beberapa penelitian telah dilakukan untuk mengetahui hubungan peningkatan kadar progesteron saat pemberian hormon hCG terhadap kehamilan. Walaupun sudah ada penelitian metaanalisis yang dilakukan untuk menganalisis pengaruh peningkatan hormonprogesteron saat pemberian hCG terhadap keberhasilan kehamilan, namun para peneliti masih tidak dapat memungkiri kemungkinan tingginya bias pada penelitian tersebut karena hampir semua penelitian menggunakan desain retrospektif dan cut off point yang sangat bervariasi sehingga sulit untuk menentukan seberapa tinggi kenaikan kadar progesteron yang dapat menyebabkan efek negatif terhadap kehamilan. Beberapa penelitian mengelompokkan batas kadar progesteron yang berbeda berdasarkan jumlah oosit yang diperoleh. ${ }^{9,10,27}$

Penelitian terbaru yang dilakukan oleh Martinez et al., (2016) dengan desain kohort prospektif melibatkan 1.901 siklus FIV sejak tahun 2009 sampai dengan 2014, menunjukkan hasil bahwa peningkatan progesteron saat pemberian hCG tidak mempengaruhi rasio kehamilan maupun kelahiran hidup, namun mempengaruhi jumlah oosit dan kadar estradiol pasca stimulasi. Pada penelitian tersebut juga ditemukan bahwa peningkatan kadar progesteron saat pemberian hCG berhubungan dengan usia yang lebih muda, tingginya kadar estradiol dan peningkatan jumlah oosit yang diperoleh.

Hasil yang didapatkan oleh Martinez et al., (2016) sesuai dengan hasil penelitian ini, dimana diperoleh peningkatan yang signifikan terhadap kadar estradiol, jumlah folikel, jumlah oosit dan jumlah embrio, serta subyek penelitian memiliki usia yang lebih muda pada kelompok dengan kadar progesteron tinggi. ${ }^{27}$ Walaupun pada analisis multivariat diperoleh hasil bahwapeningkatan jumlah oosit secara signifikan meningkatkan kadar progesteron. Hal ini sesuai dengan teori yang menyatakan pada usia yang lebih muda maka fungsi ovarium akan lebih baik, dan kemampuan untuk menghasilkan jumlah folikel, jumlah oosit dan jumlah embrio lebih banyak. Banyaknya jumlah folikel yang dihasilkan akan sebanding dengan peningkatan kadar estradiol dan progesterone..$^{5,12,20}$ 


\section{Kelemahan Penelitian}

Penelitian bersifat retrospektif, dengan mengambil data dari rekam medis pasien di klinik infertilitas Permata Hati Rumah Sakit Umum Pendidikan (RSUP) dr. Sardjito. Data yang diperoleh sangat tergantung dengan kelengkapan data yang tertulis pada rekam medis dan pengelolaan pada Instalasi Catatan Medik. Ketidaklengkapan data dan variabelvariabel yang dibutuhkan dalam penelitian mungkin dapat mempengaruhi hasil penelitian.

\section{KESIMPULAN DAN SARAN}

Pada penelitian ini disimpulkan bahwa peningkatan kadar progesteron pada saat pengambilan oosit tidak mempengaruhi keberhasilan terjadinya kehamilan pada FIV, namun secara signifikan meningkatkan jumlah oosit. Banyak faktor yang mempengaruhi keberhasilan FIV, sehingga peningkatan kadar progesteronpada saat pengambilan oosit saja tidakcukup menjadi bahan pertimbangan dalam mengambil keputusan apakah akan melanjutkan transfer embrio atau melakukan simpan beku embrio, tetapi juga mempertimbangkan faktorfaktor lain yang mempengaruhi keberhasilan FIV. Pada penelitian ini juga terdapat beberapa keterbatasan dalam metodologi penelitian dimana menggunakan desain retrospektif dengan penyebaran karakteristik subyek penelitian tidak homogen.

Penelitian yang sudah banyak dilakukan dan dianggap memiliki hasil yang signifikan terhadap keberhasilan FIV adalah mengukur peningkatan kadar progesteron pada saat pemberian hormon hCG. Namun, penelitian-penelitian tersebut masih memiliki batasan kadar yang sangat bervariasi, sehingga belum ada cut off point yang dapat digunakan dalam praktik sehari - hari.

\section{SARAN}

Penelitian lebih lanjut diperlukan dengan metode prospektif dengan memperhatikan kemungkinan pengaruh variabel-variabel lain dalam penentuan keberhasilan kehamilan seperti kualitas oosit dan kualitas embrio. Penelitian peningkatan kadar progesteron saat pemberian hCG mungkin dapat menjadi pertimbangan untuk penelitian selanjutnya,untuk menentukan cut off point yang dapat digunkan dalam pertimbangan transfer embrio dalam upaya meningkatkan keberhasilan FIV.

\section{DAFTAR PUSTAKA}

1. Fritz MA, Speroff L. Female infertility. In: Clinical Gynecologic Endocrinology and Infertility. 8th editio. Philadelphia: Lippincott Williams and Wilkins; 2011: p. 1137-90.

2. Soebijanto $S$, Muharam R. Fertilisasi In Vitro dan Transfer Embrio. In: Samsulhadi, Herndarto $\mathrm{H}$, editors. Aplikasi Klinis Induksi Ovulasi dan Stimulasi Ovarium. Bandung: Sagung Seto; 2009. p. 111-24.

3. PERFITRI. Arah dan kebijakan PERFITRI 20162019. 2015. p.1-51. Terdapat pada situs dihttp:// iwww.ia-ivf.org/publication/documentation

4. Hiferi-Perfitri-Permi. Profil ART dan angka keberhasilannya [Internet]. 2016. Terdapat pada situs: http://sisterindo.org/profil-art-danangka-keberhasilannya/

5. Salehnia M, Zavareh S. The effects of progesterone on oocyte maturation and embryo development. Fertil Steril. 2013; 7(2): 74-81.

6. Al-Azemi M, Kyrou D, Kolibianakis EM, Humaidan P, Van Vaerenbergh I, Devroey P, et al. Elevated progesterone during ovarian stimulation for IVF. Reprod Biomed Online. 2012; 24: 382-8.

7. Li R, Qiao J, Wang L, Zhen X, Lu Y. Serum progesterone concentration on day of HCG administration and IVF outcome. Reprod Biomed Online. 2008; 16(5): 627-31.

8. Bosch E, Labarta E, Crespo J, Simón C, Remohí J, Jenkins J, et al. Circulating progesterone levels and ongoing pregnancy rates in controlled ovarian stimulation cycles for in vitro fertilization: analysis of over 4000 cycles. Hum Reprod. 2010; 25(8): 2092-100.

9. Venetis CA, Kolibianakis EM, Bosdou JK, Tarlatzis BC. Progesterone elevation and probability of pregnancy after IVF: a systematic review and meta-analysis of over 60000 cycles. Hum Reprod Updat. 2013; 19(5): 433-57. 
10. Kolibianakis EM, Venetis CA, Bontis J, Tarlatzis BC. Significantly lower pregnancy rates in the presence of progesterone elevation in patients treated in $\mathrm{GnRH}$ antagonists and gonadotropins: A systematic review and meta-analysis. Curr Pharm Biotechnol. 2011; 13(3).

11. Nayak S, Ochalski ME, Fu B, Wakim KM, Chu TJ, Dong $X$, et al. Progesterone level at oocyte retrieval predicts in vitro fertilization success in a short-antagonist protocol: a prospective cohort study. Fertil Steril. 2014; 101(3): 33-5.

12. Andersen CY, Bungum L, Andersen AN, Humaidan P. Preovulatory progesterone consentration associates significantly to follicle number and LH concentration but not to pregnancy rate. Reprod Biomed Online. 2011; (23): 187-95.

13. Xu B, Li Z, Zhang H, Jin L, Li Y, Ai J, et al. Serum progesterone level effects on the outcome of in vitro fertilization in patients with different ovarian response: An analysis of more than 10,000 cycles. Fertil Steril. 2012; 97(6): 1321-7.

14. Shechter A, Lunenfeld E, Potashnik G, Glezerman $M$. The significance of serum progesterone levels on the day of hCG administration on IVF pregnancy rates. Gynecol Endocrinol. 1994; 8(2): 89-94.

15. Elnashar AM. Progesterone rise on the day of HCG administration (premature luteinization) in IVF: an overdue update. J Assist Reprod Genet. 2010 Apr; 27(4): 149-55.

16. Duleba AJ, Hausman N, Jones EE, Olive DL. Preretrieval predictors of pregnancy in IVF. J Assist Reprod Genet. 1997; 14(4): 205-11.

17. Dovey S, Mclntyre K, Jacobson D, Catov J, Wakim A. Is a premature rise in luteinizing hormone in the absence of increased progesterone levels detrimental to pregnancy outcome in $\mathrm{GnRH}$ antagonist in vitro fertilization cycles. Fertil Steril. 2011; 96(3): 585-9.

18. Zhu $\mathrm{H}$, Liu L, Yang L, Xue $Y$, Tong $X$, Jiang $L$, et al. The effect of progesterone level prior to oocyte retrieval on the numbers of oocytes retrieved and embryo quality in IVF treatment cycles: an analysis of 2,978 cycles. J Assist Reprod Genet [Internet]. 2014 Sep [cited 2015 Sep 9]; 31(9): 1183-7.
19. Donarini G, Omodei U, Falllo L, Dordoni D, Tombesi S, Suss G. Serum progesterone level on the day of oocyte retrieval correlates with the ovarian response but not predict pregnancy rate. Fertil Steril. 2010; (A): 390.

20. Niu $Z$, Feng $Y$, Zhang $A$, Sun $Y$, Zhang $H$. Progesterone levels on oocyte retrieval day can predict the quantity of viable embryos but not pregnancy outcome of intracytoplasmic sperm injection. Gynecol Endocrinol. 2008; 24: 452-458.

21. Achache $H$, Revel A. Endometrial receptivity markers, the journey to successful embryo implantation. Hum Reprod Updat. 2006; 12(6): 731-46.

22. Gardner DK, Rizk BRM., Tommaso F, editors. Human Assisted Reproductive Technology: Future Trends in Laboratory and Clinical Practice. Cambridge: Cambridge University Press; 2011.

23. Van Loendersloot LL, Van Wely M, Limpens J, Bossuyt PMM, Repping S, van der Veen F. Predictive factors in in vitro fertilization (IVF): a systematic review and meta-analysis. Hum Reprod Updat. 2010; 16(6): 577-89.

24. Sastroasmoro S, Aminullah A, Munazir Z, Rukan $Y$. Dasar-dasar metodologi penelitian klinis. 5th ed. Sastroasmoro S, Ismael S, editors. Jakarta: Saung Seto; 2016. 301-327 p.

25. Zhu $H$, Liu L, Yang L, Xue $Y$, Tong $X$, Jiang $L$, et al. The effect of progesterone level prior to oocyte retrieval on the numbers of oocytes retrieved and embryo quality in IVF treatment cycles: an analysis of 2,978 cycles. J Assist Reprod Genet. 2014; 31(9): 1183-7.

26. Liu L, Zhao L, Li TC, Zhu H, Lin X, Jin X, et al. Comparison of progesterone measurement on day of, and day after, HCG administratiion in IVFembryo transfer cycles. Reprod Biomed Online. 2014; 12(1): 23-30.

27. Martinez F, Rodriguez I, Devesa M, Buxaderas R, Gómez MJ, Coroleu B. Should progesterone on the human chorionic gonadotropin day still be measured? Fertil Steril. 2016;105(1):86-92. 